\title{
A Comparative Investigation of Cu (II), Ni (II) and Molasses Sucrose Effects on the Growth of Candida Yeasts and Metal Bioaccumulation
}

Gülşah Mersin ( $\nabla$ gulsah.mersin@gmail.com)

Cumhuriyet University: Sivas Cumhuriyet Universitesi

Ünsal Açıkel

Cumhuriyet University Faculty of Engineering Chemical Engineering Department 58140, Sivas, TURKEY Fax Number: +90-346-219 11 65 Tel : +90-346-219 10

10 / 2913 Mail: unsal.acikel@gmail.com uacikel@cumhuriyet.edu.tr

\section{Research}

Keywords: Candida lypolytica, Candida utilis, Candida tropicalis, Candida membranaefaciens, Bioaccumulation, Wastewater, Cu(II), Ni(II)

Posted Date: October 9th, 2020

DOI: https://doi.org/10.21203/rs.3.rs-87514/v1

License: (c) (i) This work is licensed under a Creative Commons Attribution 4.0 International License. Read Full License 


\section{Abstract}

In this study, microorganism growth and bioaccumulation of $\mathrm{Cu}(\mathrm{II})$ and $\mathrm{Ni}(\mathrm{II})$ ions by Candida yeasts was tested as a function of sucrose, and metal ion concentration in metal-free and metal media. The growth of the yeasts and bioaccumulation of heavy metals was studied under laboratory conditions in the batch system. The optimum pH value for maximum growth and $\mathrm{Cu}(\mathrm{II})$ and $\mathrm{Ni}(\mathrm{II})$ bioaccumulation was obtained as $4.0 \mathrm{for}$ the yeasts at $10 \mathrm{~g} / \mathrm{L}$ constant sucrose concentration. The maximum specific growth rate and microorganism concentration increased with increasing sucrose concentration up to $20 \mathrm{~g} / \mathrm{L}$ for Candida yeasts. It was observed that the metal uptake capacity of yeasts was increased with increasing initial metal concentrations in the range of 25-250 $\mathrm{mg} / \mathrm{L}$ for $\mathrm{Cu}(\mathrm{II})$ and $\mathrm{Ni}(\mathrm{II})$ ions. Although $\mathrm{Cu}(\mathrm{II})$ and $\mathrm{Ni}(\mathrm{II})$ ions caused an inhibition effect on the growth of the yeasts, Candida lipolytica showed the highest specific growth rate and metal uptake capacity among the other yeasts. It was found that the inhibition effect of the $\mathrm{Ni}(\mathrm{II})$ ion was higher than $\mathrm{Cu}(\mathrm{II})$ ion on all the yeast. Monod equation was used to study the inhibition kinetics of bioaccumulation of $\mathrm{Cu}(\mathrm{II})$ and $\mathrm{Ni}(\mathrm{II})$. It was observed that saturation constant ( $\mathrm{K}_{\mathrm{s}}$ ) increased with increasing the initial $\mathrm{Cu}$ (II) and $\mathrm{Ni}$ (II) ion concentrations whereas maximum specific growth rates $\left(\mu_{\max }\right)$ decreased.

\section{Introduction}

Heavy metal pollution due to industrial activities causes major environmental problems, even if they are found in trace amounts in wastewaters (Abbas et al. 2014). Bioaccumulation which is applied to minimize the toxic effects of heavy metals on the environment is one of the low-cost, highly efficient, and ecofriendly technologies for removing heavy metals from aqueous solutions (Wang and Chen 2006; Fadel et al. 2017). Most of the studies conducted in the last few years have focused on the use of living and non-living microorganisms such as bacteria, yeast, fungi, and algae that can be used as biomass for wastewater treatment processes (Oztürk 2007; Muñoz et. al. 2012). The biosorption of metals is affected by various factors such as pH, temperature, concentration, biomass type, contact time and presence of different metal ions in solution (Sağ 2001). Bioaccumulation is a biochemical process based on the use of living cells to remove heavy metals from wastewaters (Açikel and Alp 2001). Bioaccumulation of heavy metals by microorganisms occurs in two stages. The first is the passive step in which physical adsorption and ion exchange occurs on the surface of the microorganism. This step is very fast due to surface adsorption. The second stage of metal bioaccumulation is the intracellular metal removal stage, which occurs slower due to the metabolic activity of microorganisms (Fomina and Gadd 2014). Bioaccumulation has been studied in many studies for the removal of heavy metals from wastewater due to the active growth of cells, cell regeneration, and metabolic physical adsorption of metals. Among these studies, characterization of Saccharomyces cerevisiae and Candida krusei resistant to heavy metal ions, adsorption of $\mathrm{Cu}$ (II), and phenol by Candida tropicalis, removal of Cu (II) by Candida krusei, isolation of Cr (VI) from tannery wastes can be given as examples (Wilde and Benemann 1993; Anh et al. 2016; Vadkertiová and Sláviková 2006; Honfi et al. 2016; Luk et al. 2017; Ramírez et al. 2004). Yeast cells are widely used as a raw biosorbent in the biotechnology and pharmaceutical industries. Compared to other microorganisms, yeasts can grow in matrices containing metal ions even if high concentrations (Banafid et al. 2017). Candida species, a member of the yeast family, are one of the most popular microorganisms due to satisfying biosorption performance (Muter et al 2002). It has been found that different Candida species such as Candida utilis, Candida tropicalis, Candida membranaefaciens and Candida lipolytica can efficiently bioaccumulate heavy metals under various experimental conditions, and the metal uptake behaviors of the yeasts are different (Aksu and Dönmez 2003; Bai et al. 2019; Yin et al. 2008). The monod equation provides a simple model for describing the growth of a cell in a given nutrient media. The equation is used to define the specific growth rate of a microbial cell as a function of a limiting substrate concentration for estimate substrate biodegradation and microbial growth (Monod 1949).

$$
\mu=\frac{\mu_{m} S}{K_{s}+S}
$$

where $\mu_{\max }$ is the maximum growth rate when there is enough substrate supplied to the cell and the value exceeds the limiting substrate concentration, $\mathrm{S}>>\mathrm{K}_{\mathrm{s}}$ The constant $\mathrm{K}_{\mathrm{s}}$ is the saturation constant or half velocity constant and is equal to the concentration of the rate-limiting substrate when the specific growth rate is equal to one-half of the maximum.

If all the necessary nutrients are provided for growth media and environmental conditions are optimum, the increasing on microorganism numbers or microorganism biomass can be measured as a function of time to obtain a microbial growth curve. Different growth phases can be observed within a growth curve. These are the lag phase, exponential or lag phase, stationary phase, and death phase. Each of these phases represents a distinct growth period associated with typical physiological changes in cell culture (Ricica 1971). If Eq. 1 is rearranged:

$$
\frac{1}{\mu}=\frac{1}{\mu_{m}}+\frac{K_{s}}{\mu_{m}} \frac{1}{s}
$$

$\mathrm{K}_{\mathrm{s}}$ and $\mu_{\mathrm{m}}$ values can be determined from the $1 / \mu_{\mathrm{m}}$ versus $1 / \mathrm{S}$ plot. The slope of $\mathrm{K}_{\mathrm{s}} / \mu_{\mathrm{m}}$ and $1 / \mu_{\mathrm{m}}$ gives a line intersecting the $y$-axis. When molasses sucrose is used as the main substrate in growth media containing high concentrations of inhibitory (toxic) substances such as heavy metals, microbial growth is inhibited and the growth rate depends on inhibitor concentration. The steady-state specific growth rate of microbial species was assumed to fit the Monod growth kinetics described in Eq. 1. For batch cultures, growth rate:

$$
\frac{d x}{d t}=\mu X \text { or } \operatorname{In}\left(\frac{x}{x_{0}}\right)=\mu t
$$


Where $\mathrm{Xo}_{\mathrm{o}}$ is the initial biomass concentration $(\mathrm{g} / \mathrm{L}), \mathrm{X}$ is the biomass concentration $(\mathrm{g} / \mathrm{L})$ at time $\mathrm{t}$ and $\mu$ is the specific growth rate $(\mathrm{h}-1)$. Metal ion removal by microorganisms is calculated by the mass balance equation:

$$
q_{e}=\frac{\left(C_{o}-C_{e}\right) V}{m}
$$

Where $\mathrm{q}_{\mathrm{e}}$ is metal ion uptake per unit mass of biomass at equilibrium ( $\mathrm{mg} / \mathrm{g}$ biomass), $\mathrm{C}_{\mathrm{e}}$, metal ion concentration in solution at equilibrium (mg / $\mathrm{L}$ ), $\mathrm{C}_{\mathrm{O}}$, initial metal ion concentration in solution ( $\mathrm{mg} / \mathrm{L}), \mathrm{v}$, initial metal ion solution volume $(\mathrm{L})$ of and $\mathrm{m}$ is the mass of biomass ( $\mathrm{g}$ ) (Horsfall and Spiff 2005$)$.

The aim of this study is to investigate the combined effect of molasses sucrose and $\mathrm{Cu}$ (II) and Ni (II) ions on growth and bioaccumulation properties of Candida species. In present study, the inhibition effects of $\mathrm{Cu}$ (II) and Ni (II) ions and the specific growth rates and kinetic constants was examined. Candida species was chosen due to their highly resistant to $\mathrm{Cu}$ (II) and Ni (II) ions and can grow at acidic pH (Dönmez and Aksu 2001). Furthermore, copper and nickel are common pollutants of industrial wastewaters. Molasses sucrose contains high sucrose and other nutrients and provides low cost, easy accessibility and storage (Tchounwou et al. 2012; Joseph 2009; Gönen and Aksu 2008).

\section{Material And Method}

\subsection{Reagents}

The chemicals used in the experiments were purchased from Sigma-Aldrich. Microorganisms which was used in this study includes ATCC ${ }^{\circledR} 201377^{\mathrm{TM}} C$. membranafiens, ATCC $\AA 9950^{\mathrm{TM}}$ C. utilis, ATCC $\AA 13803^{\mathrm{TM}}$ C. tropicalis, ATCC $\AA 9733^{\mathrm{TM}}$ C. lypolitica. The Candida type yeast strains obtained from the Biology Department of Ankara University. Molasses sucrose was supplied from the sugar factory in Ankara (Turkey).

\subsection{Preparation of microorganism growth media with and without a single metal ion}

Molasses sucrose, a sugar industry waste, has been used as the main carbon source for the growth of microorganism. Microorganisms showed maximum bioaccumulation at optimum $\mathrm{pH}$ value and bioaccumulation experiments were conducted at this $\mathrm{pH}$. Yeasts were reproduced in aqueous media containing molasses sucrose (1-10 g / L) with $(1 \mathrm{~g} / \mathrm{L})\left(\mathrm{NH}_{4}\right) 2 \mathrm{SO}_{4}$ and $(1 \mathrm{~g} / \mathrm{L}) \mathrm{K}_{2} \mathrm{PO}_{4}$ at $25^{\circ} \mathrm{C}$ and $\mathrm{pH}$ 4. The growth and cultivation media sterilized in an autoclave operating at $121^{\circ} \mathrm{C}$ at 0.99 bar for 15 minutes. Subcultures were grown for 4 days at a rotating speed of $150 \mathrm{rpm}$. $1000 \mathrm{mg} / \mathrm{L} \mathrm{Cu}$ (II) and Ni (II) stock solutions were prepared with $\mathrm{Cu}\left(\mathrm{NO}_{3}\right)_{2} 3 \mathrm{H}_{2} \mathrm{O}$ and $\mathrm{Ni}\left(\mathrm{NO}_{3}\right)_{2} 6 \mathrm{H}_{2} \mathrm{O}$ with distilled water. Working solutions $(25-250 \mathrm{mg} / \mathrm{L})$ were prepared by diluting stock solutions $(1000 \mathrm{mg} / \mathrm{L})$ to obtain different metal ion concentrations. The $\mathrm{pH}$ of the working solutions was adjusted using a pH meter and by adding either $0.1 \mathrm{~N} \mathrm{NaOH}$ and $\mathrm{HNO}_{3}$ as appropriate.

\subsection{Metal adaptation of Candida yeasts}

Candida lipolytica, Candida utilis, Candida tropicalis, Candida membranifaciens was adapted to single Cu (II) and Ni (II) ions in culture media. The adaptation was conducted exposing yeast cells to $\mathrm{Cu}$ (II) and Ni (II) ions during the growth stage to increase metal resistance. Subcultures was obtained through different concentrations of $\mathrm{Cu}(\mathrm{II})$ and $\mathrm{Ni}(\mathrm{II})$ ions in the range of $25-250 \mathrm{mg} / \mathrm{L}$ at changing sucrose concentrations (1-20 g/L) in growth media. Yeast cultures that resistant to $25 \mathrm{mg} / \mathrm{L} \mathrm{Cu}(\mathrm{II})$ and $\mathrm{Ni}(\mathrm{II})$ ions at $10 \mathrm{~g} / \mathrm{L}$ molasses sucrose was used to the first inoculation. $1 \mathrm{~mL}$ culture medium was used to inoculate the next culture medium containing $50 \mathrm{mg} / \mathrm{L} \mathrm{Cu}$ (II) and Ni (II) ions at the same molasses sucrose concentration when the stressed growth culture containing Candida and metal reached to the exponential growth phase. In the metal adaptation process, the metal ion concentration was increased and the sucrose concentration was changed in the defined concentration range. Metal adaptation experiments were performed with $250 \mathrm{~mL}$ flasks containing $100 \mathrm{~mL}$ of media at $150 \mathrm{rpm}$ and $25^{\circ} \mathrm{C}$.

\subsection{Analysis of microorganism, metal and molasses sucrose concentration}

$5 \mathrm{~mL}$ samples were centrifuged at $3000 \mathrm{rpm}$ for $5 \mathrm{~min}$ and the supernatant fluid used to determine molasses sucrose and $\mathrm{Cu}(\mathrm{II})$ and $\mathrm{Ni}(\mathrm{II})$ ion concentrations. After centrifugation, the solid residual was used to analyze yeast concentration. Molasses sucrose concentration was examined at $575 \mathrm{~nm}$ by Miller method. For microorganism concentration in the sample supernatant, the turbidity of the fermentation media was measured at $360 \mathrm{~nm}$. Microorganism concentration was determined using a calibration curve relating the wet weight of the biomass to the dry weight of the biomass at $25 \circ \mathrm{C}$. Sodium diethyldithiocarbamate was used as the complexing agent for $\mathrm{Cu}(\mathrm{II})$ and $\mathrm{Ni}(\mathrm{II})$ ions. Residual metal concentrations was measured at $460 \mathrm{~nm}$ and $340 \mathrm{~nm}$ for $\mathrm{Cu}(\mathrm{II})$ and $\mathrm{Ni}(\mathrm{II})$, respectively (Snell and Snell 1959; Forouchi and Gunn 1983).

\section{Results And Discussion}

Bioaccumulation and growth properties of metal adapted Candida yeasts was investigated as a function of initial $\mathrm{Cu}(\mathrm{II})$ and $\mathrm{Ni}(\mathrm{II})$ ions and molases sucrose concentration at $\mathrm{pH} 4$ and $25^{\circ} \mathrm{C}$. The uptake yield (Uptake \%) was determined as the ratio of bioaccumulated concentration of metal ion at the end of microbial growth to the initial metal ion concentration. The results are given as the units of bioaccumulated metal ion concentration $\left(C_{a c c, m}\right.$ : mg / $\left.L\right)$ and specific metal ion uptake determined as the amount of metal ion per unit of dry weight of cells $\left(\mathrm{q}_{\mathrm{m}}: \mathrm{mg} / \mathrm{g}\right)$, dried cell and accumulated metal ion concentrations in any time $\left(\mathrm{X}: \mathrm{g} \mathrm{L} ; \mathrm{C}_{\mathrm{acc}}: \mathrm{mg} / \mathrm{L}\right)$, specific growth rate of yeast $\left(\mu: \mathrm{h}^{-1}\right)$. The results showed that the metal uptake capacity of Candida yeasts were different from each other due to the physiological properties of the yeasts (Pabst et al 2010). Researchers reported that microorganisms demonstrate resistance to metal ions due to the environmental toxic effects of heavy metals. For efficient removal of heavy metals from wastewaters, optimum pH and temperature should be investigated. Generally, metal bioaccumulation occurs at $25-30^{\circ} \mathrm{C}$ for yeasts (Abbas et al. 2014). High temperatures above $45^{\circ} \mathrm{C}$ may damage cell proteins and decrease metal uptake capacity (Vadkertiová and Sláviková 2006). 


\subsection{The effect of initial pH on the growth of Candida species}

The effect of $\mathrm{pH}$ on the specific growth rate of Candida yeasts and maximum dry microorganism concentrations was investigated at $25^{\circ} \mathrm{C}$ in aqueous medium containing molasses sucrose $(1-10 \mathrm{~g} / \mathrm{L}),(1 \mathrm{~g} / \mathrm{L})\left(\mathrm{NH}_{4}\right) 2 \mathrm{SO}_{4}$ and $(1 \mathrm{~g} / \mathrm{L}) \mathrm{K}_{2} \mathrm{PO}_{4}$. The effect of pH was tested inoculating the culture medium in the $\mathrm{pH}$ range of 2.0-5.0. The initial $\mathrm{pH}$ value is a vital factor affecting the growth of Candida yeasts. All yeasts showed adaptation and growth in medium with $\mathrm{pH}$ values at 2.0-5.0. Besides some special cases, the low initial pH showed the ability to prolong the yeast lag phase, altering the consumption rate of total sugar, affecting the accumulated mass loss. Maximum specific growth rate and microorganism concentration were obtained at pH 4.0 (Fig. 1 ). Candida lypolytica showed the highest specific growth rate and microorganisms concentration (specific growth rate $0.253 \mathrm{~h}^{-1}$ at $\mathrm{pH} 4.0$, microorganism concentration $0.308 \mathrm{~g} / \mathrm{L}$ ). Optimum growth conditions for living biomass were determined as $\mathrm{pH} 4.0$ and $25^{\circ} \mathrm{C}$ for Candida lipolytica, Candida utilis, Candida tropicalis, Candida membranifaciens (Dönmez and Aksu 2001; Aksu and Dönmez 2000).

\subsection{Effect of initial molasses sucrose concentration on growth of Candida species}

The effect of initial molasses sucrose concentration on the growth rate of Candida species in metal-free media was investigated in the sucrose concentration range of $1.0-20.0 \mathrm{~g} / \mathrm{L}$, at pH 4.0 and at $25 \circ \mathrm{C}$. During experimental studies, molasses sucrose was used as the sole and main carbon source. It was observed that the yeast concentrations and specific growth rates increased with increasing initial sucrose concentration up to $20 \mathrm{~g} / \mathrm{L}$ (Fig. 2). Substrate inhibition was not seen. As a carbon source, molasses sucrose is suitable for microbial growth (Bamforth and Cook 2019). Aksu and Dönmez (2000) used molasses sucrose as a carbon source to obtain an efficient metal removal by Kluyveromyces marxianus and Candida utilis. They observed that the specific growth rate of microorganisms and the microorganism concentration increased with increasing initial sucrose concentration (Aksu and Dönmez 2000). Kujan et al. (1995) studied the removal of Cd (II) ions by Candida utilis and reported that bioaccumulation depends on the organic carbon source as a substrate. When glucose was used as a carbon source, bioaccumulation capacity was ten times higher than xylose (Kujan et al. 1995).

\subsection{Effect of initial $\mathrm{Cu}$ (II) and Ni (II) ion concentrations on growth of Candida species}

The effect of $\mathrm{Cu}(\mathrm{II})$ and $\mathrm{Ni}(\mathrm{II})$ ion concentrations on the specific growth rate and microorganism concentration of Candida species were investigated at different initial $\mathrm{Cu}(\mathrm{II})$ and $\mathrm{Ni}$ (II) concentrations ranging from 25 to $250 \mathrm{mg} / \mathrm{L}$. It was observed that specific growth rates and microorganism concentrations decreased with increasing $\mathrm{Cu}$ (II) and Ni (II) ion concentrations. Single Cu (II) and Ni (II) ions inhibited the growth of yeasts in the medium. It was found that the inhibition effect of $\mathrm{Ni}(\mathrm{II})$ ions on yeast growth was higher than $\mathrm{Cu}$ (II) ions for all yeasts. Candida lipolytica showed the highest specific growth rate and microorganism concentration while Candida utilis had a minimum specific growth rate and microorganism concentration among the yeasts. Growth parameters of $\mu$ max and $\mathrm{Ks}$ were determined using the double reciprocal plot of the Monod Eq. (1). When initial $\mathrm{Cu}(\mathrm{II})$ and $\mathrm{Ni}(\mathrm{II})$ ion concentrations were increased, the maximum specific growth rate of the yeasts decreased while saturation constants increased (Table 1). Compared to metal-free media, the decrease in the specific growth rates of the yeast was higher than yeast concentrations in medium containing 100 and $250 \mathrm{mg} / \mathrm{L} \mathrm{Cu}$ (II) and Ni (II) at a constant $10 \mathrm{~g} / \mathrm{L}$ molasses sucrose (Table 2, Table 3).

Table 1

Comparison of the maximum specific growth rates and the saturation constants in the presence of increasing concentrations of

\begin{tabular}{|c|c|c|c|c|c|c|c|c|c|}
\hline \multicolumn{2}{|l|}{ Metal Ion } & \multicolumn{2}{|c|}{ Candida membranefeciens } & \multicolumn{2}{|c|}{ Candida utilis } & \multicolumn{2}{|c|}{ Candida tropicalis } & \multicolumn{2}{|c|}{ Candida lipolytica } \\
\hline $\mathrm{C}_{\mathrm{iCu}} \mathrm{mg} / \mathrm{L}$ & $\mathrm{C}_{\mathrm{iNi}} \mathrm{mg} / \mathrm{L}$ & $\mu_{\max }\left(\mathrm{h}^{-1}\right)$ & $\mathrm{K}_{\mathrm{s}}(\mathrm{g} / \mathrm{L})$ & $\mu_{\max }\left(\mathrm{h}^{-1}\right)$ & $\mathrm{K}_{\mathrm{s}}(\mathrm{g} / \mathrm{L})$ & $\mu_{\max }\left(h^{-1}\right)$ & $\mathrm{K}_{\mathrm{s}}(\mathrm{g} / \mathrm{L})$ & $\mu_{\max }\left(\mathrm{h}^{-1}\right)$ & $\mathrm{K}_{\mathrm{s}}(\mathrm{g} / \mathrm{L})$ \\
\hline 25.0 & 0.0 & 0.3542 & 5.3990 & 0.3415 & 5.8051 & 0.3743 & 4.555 & 0.4223 & 5.0800 \\
\hline 50.0 & 0.0 & 0.3542 & 5.7532 & 0.3314 & 5.7232 & 0.3579 & 4.1755 & 0.4254 & 5.3688 \\
\hline 100.0 & 0.0 & 0.3370 & 5.3540 & 0.3414 & 6.4721 & 0.3631 & 4.6773 & 0.3885 & 4.5681 \\
\hline 150.0 & 0.0 & 0.3352 & 6.0040 & 0.3148 & 6.1285 & 0.3354 & 4.4410 & 0.3907 & 5.2713 \\
\hline 200.0 & 0.0 & 0.3367 & 6.5868 & 0.2995 & 6.0334 & 0.3380 & 4.8870 & 0.3781 & 5.3783 \\
\hline 250.0 & 0.0 & 0.3108 & 6.7714 & 0.2851 & 6.5197 & 0.3137 & 4.984 & 0.3358 & 4.9207 \\
\hline 0.0 & 25.0 & 0.3468 & 5.7250 & 0.3196 & 5.600 & 0.3525 & 4.2434 & 0.3450 & 4.4736 \\
\hline 0.0 & 50.0 & 0.3314 & 5.4340 & 0.3053 & 5.2806 & 0.3651 & 4.7962 & 0.4070 & 5.3946 \\
\hline 0.0 & 100.0 & 0.3337 & 5.7184 & 0.3021 & 5.4083 & 0.3566 & 5.0135 & 0.3952 & 5.2681 \\
\hline 0.0 & 150.0 & 0.3177 & 6.6938 & 0.2826 & 6.0892 & 0.3048 & 4.2690 & 0.3582 & 5.3844 \\
\hline 0.0 & 200.0 & 0.3097 & 7.0040 & 0.2783 & 6.3743 & 0.3099 & 5.1117 & 0.3286 & 4.9181 \\
\hline 0.0 & 250.0 & 0.2671 & 6.2658 & 0.2647 & 7.1964 & 0.2840 & 5.2692 & 0.3174 & 5.7960 \\
\hline
\end{tabular}


Table 2

Comparison of decrease in maximum specific growth rates obtained in the metal-free fermentation media with $\mathrm{Cu}(\mathrm{II})$ and $\mathrm{Ni}(\mathrm{II})$ ions present as the single metal at 100 and $250 \mathrm{mg} / \mathrm{L}$ (So: $10 \mathrm{~g} / \mathrm{L} ; \mathrm{pH}: 4, \mathrm{~T}: 25^{\circ} \mathrm{C} ; \mathrm{SR}: 150 \mathrm{rpm}$ ).

\begin{tabular}{|c|c|c|c|c|c|c|c|c|c|}
\hline \multicolumn{2}{|l|}{ Metal lon } & \multicolumn{2}{|c|}{ Candida membranefeciens } & \multicolumn{2}{|c|}{ Candida utilis } & \multicolumn{2}{|c|}{ Candida tropicalis } & \multicolumn{2}{|c|}{ Candida lypolytica } \\
\hline $\mathrm{C}_{\mathrm{iCu}}(\mathrm{mg} / \mathrm{L})$ & $\mathrm{C}_{\mathrm{iNi}}(\mathrm{mg} / \mathrm{L})$ & $\mu_{\max }\left(\mathrm{h}^{-1}\right)$ & $\%$ Decrease & $\mu_{\max }\left(\mathrm{h}^{-1}\right)$ & $\%$ Decrease & $\mu_{\max }\left(\mathrm{h}^{-1}\right)$ & $\%$ Decrease & $\mu_{\max }\left(\mathrm{h}^{-1}\right)$ & $\%$ Decrease \\
\hline 0.0 & 0.0 & 0.245 & 0.0 & 0.238 & 0.0 & 0.289 & 0.0 & 0.308 & 0.0 \\
\hline 100.0 & 0.0 & 0.223 & 9.0 & 0.207 & 13.0 & 0.258 & 10.7 & 0.278 & 9.7 \\
\hline 250.0 & 0.0 & 0.189 & 22.9 & 0.175 & 26.5 & 0.218 & 24.6 & 0.236 & 23.4 \\
\hline 0.0 & 100.0 & 0.215 & 12.2 & 0.199 & 16.4 & 0.249 & 13.8 & 0.268 & 13.0 \\
\hline 0.0 & 250.0 & 0.170 & 30.6 & 0.157 & 34.0 & 0.197 & 31.8 & 0.215 & 30.2 \\
\hline
\end{tabular}

Table 3

Comparison of decrease in maximum dried microorganism concentrations obtained in the metal-free fermentation media with $\mathrm{Cu}(\mathrm{II})$ and $\mathrm{Ni}(\mathrm{II})$ ions present as the single metal at 100 and $250 \mathrm{mg} / \mathrm{L}$ (So: $10 \mathrm{~g} / \mathrm{L} ; \mathrm{pH}: 4, \mathrm{~T}: 25^{\circ} \mathrm{C}$; SR: $150 \mathrm{rpm}$ ).

\begin{tabular}{|c|c|c|c|c|c|c|c|c|c|}
\hline \multicolumn{2}{|l|}{ Metal lon } & \multicolumn{2}{|c|}{ Candida membranefeciens } & \multicolumn{2}{|c|}{ Candida utilis } & \multicolumn{2}{|c|}{ Candida tropicalis } & \multicolumn{2}{|c|}{ Candida lypolytica } \\
\hline $\mathrm{C}_{\mathrm{iCu}}(\mathrm{mg} / \mathrm{L})$ & $\mathrm{C}_{\mathrm{iNi}}(\mathrm{mg} / \mathrm{L})$ & $\mathrm{X}_{\max }(\mathrm{g} / \mathrm{L})$ & \% Decrease & $\mathrm{X}_{\max }(\mathrm{g} / \mathrm{L})$ & $\%$ Decrease & $\mathrm{X}_{\max }(\mathrm{g} / \mathrm{L})$ & $\%$ Decrease & $\mathrm{X}_{\max }(\mathrm{g} / \mathrm{L})$ & \% Decrease \\
\hline 100.0 & 0.0 & 2.666 & 2.4 & 2.456 & 7.6 & 2.831 & 5.6 & 2.968 & 4.6 \\
\hline 250.0 & 0.0 & 2.335 & 14.5 & 2.148 & 19.2 & 2.483 & 17.2 & 2.607 & 16.2 \\
\hline 0.0 & 100.0 & 2.574 & 5.8 & 2.371 & 10.8 & 2.735 & 8.8 & 2.868 & 7.8 \\
\hline
\end{tabular}

\subsection{Bioaccumulation of $\mathrm{Cu}(\mathrm{II})$ and $\mathrm{Ni}(\mathrm{II})$ ions by Candida species}

The effect of $\mathrm{Cu}(\mathrm{II})$ nd $\mathrm{Ni}(\mathrm{II})$ ions and molasses sucrose on the bioaccumulation properties of adapted Candida yeasts was studied. Initial metal ion concentration in the feed medium was varied in the range 25-250 mg / L for Cu(II) and Ni(II) at 1-20 g/L molasses concentration. It was observed that bioaccumulated $\mathrm{Cu}(\mathrm{II})$ and $\mathrm{Ni}(\mathrm{II})$ ions and microorganism growth increased with increasing initial molasses sucrose concentrations for all yeasts. Results showed that the uptake efficiency of $\mathrm{Cu}$ (II) ions was higher than $\mathrm{Ni}$ (II), and Candida lypolitica performed the highest removal efficiency in medium containing both single $\mathrm{Cu}$ (II) and $\mathrm{Ni}$ (II) ions. It should be noted that increasing sucrose concentration significantly increased the growth and metal holding capacity of microorganisms. It was seen that the amount of $\mathrm{Cu}$ (II) and Ni (II) ions uptake per gram dry microorganism increased with increasing the initial metal concentrations up to $250 \mathrm{mg} / \mathrm{L}$ (Table 4 and Table 5). Dursun et al. (2003) observed the inhibition effects of metal ions on the growth of $A$. niger and obtained maximum removal capacities of $15.6 \mathrm{mg} / \mathrm{g}$ and $34.4 \mathrm{mg} / \mathrm{g}$ at initial Cu (II) and Pb (II) concentrations of $100.0 \mathrm{mg} / \mathrm{L}$, respectively. (Dursun et al.2003b). Aksu and Dönmez (2001) investigated heavy metal bioaccumulation with Candida sp. They reported that specific metal uptake was $36.9 \mathrm{mg}$ Cu (II)/ $\mathrm{g}$ at $783.6 \mathrm{mg} / \mathrm{L}$ initial Cu(II) concentration and $46.8 \mathrm{mg} \mathrm{Ni}(\mathrm{II})$ / g at $321.5 \mathrm{mg} / \mathrm{L}$ initial Ni (II) concentration (Dönmez and Aksu 2001). Gönen and Aksu (2008) investigated the $\mathrm{Cu}$ (II) removal efficiency with Candida utilis as a function of molasses sucrose and metal ion concentration. They found that the maximum metal removal efficiency was 34.2\% in growth medium containing $15 \mathrm{~g} / \mathrm{L}$ sucrose and $50 \mathrm{mg} / \mathrm{L}$ Cu (II) (Gönen and Aksu 2008). Bioaccumulated Cu (II) ion and specific Cu (II) uptake were determined as $46.80 \mathrm{mg} / \mathrm{L}$ and $17.56 \mathrm{mg} / \mathrm{g}, 38.4 \mathrm{mg} / \mathrm{L}$ and $15.64 \mathrm{mg} / \mathrm{g}, 51.48 \mathrm{mg} / \mathrm{L}$ and $18.18 \mathrm{mg} / \mathrm{g}, 53.60 \mathrm{mg} / \mathrm{L}$ and $18.98 \mathrm{mg} / \mathrm{g}$ recpectively for Candida membranaefaciens, Candida utilis, Candida tropicalis, Candida lypolitica in fermentation media containing $10 \mathrm{~g} / \mathrm{L}$ constant initial molasses sucrose and $100 \mathrm{mg} / \mathrm{L} \mathrm{Cu}(\mathrm{II})$. Bioaccumulated $\mathrm{Ni}(\mathrm{II})$ ions and spesicific Ni(II) uptake were determined as $37.70 \mathrm{mg} / \mathrm{L}$ and $15.42 \mathrm{mg} / \mathrm{g}, 31.20 \mathrm{mg} / \mathrm{L}$ and $13.16 \mathrm{mg} / \mathrm{g}, 44.30 \mathrm{mg} / \mathrm{L}$ and16.20 mg/g, $48.28 \mathrm{mg} / \mathrm{L}$ and $17.04 \mathrm{mg} / \mathrm{g}$ recpectively for Candida membranaefaciens, Candida utilis, Candida tropicalis, Candida lypolitica in fermentation media containing $10 \mathrm{~g} / \mathrm{L}$ constant initial molasses sucrose and $100 \mathrm{mg} / \mathrm{L} \mathrm{Ni(II).}$ 
Table 4

Comparison of the maximum $\mathrm{Cu}(\mathrm{II})$ biomass concentration, the bioaccumulated $\mathrm{Cu}(\mathrm{II})$, the specific $\mathrm{Cu}(\mathrm{II})$ uptake, and the $\mathrm{Cu}(\mathrm{II})$ metal ion bioaccumulation eff containing single $\mathrm{Cu}(\mathrm{II})$ ion ( $\mathrm{pH} 4.0 ; \mathrm{T}=25^{\circ} \mathrm{C}$; SR:150 rpm)

\begin{tabular}{|c|c|c|c|c|c|c|c|c|c|c|c|c|c|c|}
\hline \multirow[b]{2}{*}{$\begin{array}{l}S_{i} \\
(g / L)\end{array}$} & \multirow[b]{2}{*}{$\begin{array}{l}\mathrm{C}_{\mathrm{i}} \\
(\mathrm{mg} / \mathrm{L})\end{array}$} & \multicolumn{4}{|c|}{ Candida membranaefaciens } & \multicolumn{4}{|c|}{ Candida utilis } & \multicolumn{4}{|c|}{ Candida tropicolis } & \multirow{2}{*}{$\begin{array}{l}\text { Candic } \\
\mathrm{X}_{\max } \\
(\mathrm{mg} / \mathrm{L})\end{array}$} \\
\hline & & $\begin{array}{l}X_{\max } \\
(\mathrm{mg} / \mathrm{L})\end{array}$ & $\begin{array}{l}\mathrm{C}_{\mathrm{acc}, \mathrm{Cu}} \\
\text { (mg/L) }\end{array}$ & $\begin{array}{l}\mathrm{q}_{\mathrm{cu}} \\
(\mathrm{mg} / \mathrm{g})\end{array}$ & \%uptake & $\begin{array}{l}X_{\max } \\
(\mathrm{mg} / \mathrm{L})\end{array}$ & $\begin{array}{l}\mathrm{C}_{\mathrm{acc}, \mathrm{Cu}} \\
(\mathrm{mg} / \mathrm{L})\end{array}$ & $\begin{array}{l}\mathrm{q}_{\mathrm{Cu}} \\
(\mathrm{mg} / \mathrm{g})\end{array}$ & \%uptake & $\begin{array}{l}X_{\max } \\
(\mathrm{mg} / \mathrm{L})\end{array}$ & $\begin{array}{l}\mathrm{C}_{\mathrm{acc}, \mathrm{Cu}} \\
\text { (mg/L) }\end{array}$ & $\begin{array}{l}\mathrm{q}_{\mathrm{Cu}} \\
(\mathrm{mg} / \mathrm{g})\end{array}$ & \%uptake & \\
\hline 1 & 0 & 1.36 & & & & 1.07 & & & & 1.47 & & & & 1.95 \\
\hline 5 & 0 & 2.23 & & & & 1.98 & & & & 2.53 & & & & 2.62 \\
\hline 10 & 0 & 2.85 & & & & 2.65 & & & & 2.99 & & & & 3.11 \\
\hline 20 & 0 & 3.11 & & & & 3.05 & & & & 3.24 & & & & 3.48 \\
\hline 1 & 25 & 1.30 & 2.50 & 1.91 & 10.00 & 1.01 & 2.13 & 2.09 & 8.52 & 1.43 & 2.88 & 2.00 & 11.52 & 1.92 \\
\hline 5 & 25 & 2.15 & 8.50 & 3.95 & 34.00 & 1.89 & 7.23 & 3.81 & 28.92 & 2.46 & 9.78 & 3.96 & 39.12 & 2.58 \\
\hline 10 & 25 & 2.76 & 14.50 & 5.25 & 58.00 & 2.54 & 12.60 & 4.95 & 50.40 & 2.93 & 16.40 & 5.59 & 65.60 & 3.07 \\
\hline 20 & 25 & 3.01 & 17.10 & 5.67 & 68.40 & 2.93 & 15.1 & 5.15 & 60.4 & 3.17 & 19.67 & 6.19 & 78.68 & 3.45 \\
\hline 1 & 100 & 1.24 & 6.88 & 5.54 & 6.88 & 0.96 & 5.50 & 5.70 & 5.50 & 1.36 & 7.56 & 5.56 & 7.56 & 1.82 \\
\hline 5 & 100 & 2.00 & 29.00 & 14.09 & 29.00 & 1.81 & 23.20 & 12.80 & 23.20 & 2.36 & 35.30 & 14.95 & 35.30 & 2.47 \\
\hline 10 & 100 & 2.66 & 46.80 & 17.56 & 46.80 & 2.45 & 38.40 & 15.64 & 38.40 & 2.83 & 51.48 & 18.18 & 51.48 & 2.96 \\
\hline 20 & 100 & 2.92 & 58.47 & 19.99 & 58.47 & 2.84 & 46.77 & 16.47 & 46.77 & 3.08 & 64.31 & 20.87 & 64.31 & 3.34 \\
\hline 1 & 200 & 1.14 & 14.60 & 12.75 & 7.30 & 0.88 & 8.65 & 9.72 & 23.38 & 1.25 & 16.06 & 12.77 & 8.03 & 1.69 \\
\hline 5 & 200 & 1.91 & 50.70 & 26.41 & 25.35 & 1.68 & 41.35 & 24.49 & 4.32 & 2.20 & 58.90 & 26.73 & 29.45 & 2.31 \\
\hline 10 & 200 & 2.51 & 79.80 & 31.77 & 39.90 & 2.31 & 68.70 & 29.71 & 20.67 & 2.66 & 88.20 & 33.04 & 44.10 & 2.79 \\
\hline 20 & 200 & 2.76 & 95.88 & 34.63 & 47.94 & 2.68 & 83.37 & 31.02 & 34.35 & 2.91 & 105.46 & 36.13 & 52.73 & 3.17 \\
\hline 1 & 250 & 1.04 & 11.60 & 11.05 & 4.64 & 0.81 & 8.50 & 10.43 & 3.40 & 1.15 & 15.20 & 13.18 & 6.08 & 1.56 \\
\hline 5 & 250 & 1.77 & 57.07 & 32.20 & 22.82 & 1.55 & 47.56 & 30.53 & 19.02 & 2.03 & 66.80 & 32.80 & 26.72 & 2.13 \\
\hline 10 & 250 & 2.33 & 94.81 & 40.61 & 37.92 & 2.14 & 79.01 & 36.79 & 31.60 & 2.48 & 104.29 & 42.00 & 41.71 & 2.60 \\
\hline 20 & 250 & 2.58 & 115.05 & 44.56 & 46.02 & 2.50 & 95.88 & 38.29 & 38.35 & 2.72 & 126.56 & 46.46 & 50.62 & 2.96 \\
\hline
\end{tabular}


Table 5

Comparison of the maximum $\mathrm{Ni}(\mathrm{II})$ biomass concentration, the bioaccumulated $\mathrm{Ni}(\mathrm{II})$, the specific $\mathrm{Ni}(\mathrm{II})$ uptake, and the $\mathrm{Ni}(\mathrm{II})$ metal ion bioaccumulation effic containing single $\mathrm{Ni}(\mathrm{II})$ ion ( $\mathrm{pH} 4.0 ; \mathrm{T}=25^{\circ} \mathrm{C}$; SR: $\left.150 \mathrm{rpm}\right)$

\begin{tabular}{|c|c|c|c|c|c|c|c|c|c|c|c|c|c|c|}
\hline \multirow[b]{2}{*}{$\begin{array}{l}\mathrm{S}_{\mathrm{i}} \\
(\mathrm{g} / \mathrm{L})\end{array}$} & \multirow[b]{2}{*}{$\begin{array}{l}\mathrm{C}_{\mathrm{i}} \\
(\mathrm{mg} / \mathrm{L})\end{array}$} & \multicolumn{4}{|c|}{ Candida membranaefaciens } & \multicolumn{4}{|c|}{ Candida utilis } & \multicolumn{4}{|c|}{ Candida tropicolis } & \multirow{2}{*}{$\begin{array}{l}\text { Candic } \\
\mathrm{X}_{\max } \\
(\mathrm{mg} / \mathrm{L})\end{array}$} \\
\hline & & $\begin{array}{l}X_{\max } \\
(\mathrm{mg} / \mathrm{L})\end{array}$ & $\begin{array}{l}\mathrm{C}_{\mathrm{acc}, \mathrm{Ni}} \\
(\mathrm{mg} / \mathrm{L})\end{array}$ & $\begin{array}{l}q_{N i} \\
(m g / g)\end{array}$ & \%uptake & $\begin{array}{l}X_{\max } \\
(\mathrm{mg} / \mathrm{L})\end{array}$ & $\begin{array}{l}\mathrm{C}_{\mathrm{acc}, \mathrm{Ni}} \\
(\mathrm{mg} / \mathrm{L})\end{array}$ & $\begin{array}{l}\mathrm{q}_{\mathrm{Ni}} \\
(\mathrm{mg} / \mathrm{g})\end{array}$ & \%uptake & $\begin{array}{l}X_{\max } \\
(\mathrm{mg} / \mathrm{L})\end{array}$ & $\begin{array}{l}\mathrm{C}_{\mathrm{acc}, \mathrm{Ni}} \\
(\mathrm{mg} / \mathrm{L})\end{array}$ & $\begin{array}{l}\mathrm{qNi} \\
(\mathrm{mg} / \mathrm{g})\end{array}$ & \%uptake & \\
\hline 1 & 0 & 1.36 & & & & 1.07 & & & & 1.47 & & & & 1.52 \\
\hline 5 & 0 & 2.23 & & & & 1.98 & & & & 2.53 & & & & 2.62 \\
\hline 10 & 0 & 2.85 & & & & 2.65 & & & & 2.99 & & & & 3.11 \\
\hline 20 & 0 & 3.11 & & & & 3.05 & & & & 3.24 & & & & 3.48 \\
\hline 1 & 25 & 1.25 & 2.04 & 3.11 & 8.16 & 0.97 & 1.51 & 2.99 & 6.04 & 1.37 & 2.36 & 3.12 & 9.44 & 1.43 \\
\hline 5 & 25 & 2.07 & 7.31 & 6.53 & 29.24 & 1.82 & 5.70 & 6.31 & 22.80 & 2.37 & 8.02 & 6.64 & 32.08 & 2.48 \\
\hline 10 & 25 & 2.67 & 12.20 & 8.46 & 48.80 & 2.46 & 10.10 & 8.23 & 40,40 & 2.83 & 13.50 & 8.60 & 54.00 & 2.97 \\
\hline 20 & 25 & 2.92 & 14.71 & 9.42 & 58.84 & 2.84 & 12.08 & 8.47 & 48.32 & 3.08 & 16.13 & 10.20 & 64.52 & 3.34 \\
\hline 1 & 100 & 1.18 & 5.84 & 6.91 & 5.84 & 0.92 & 4.47 & 5.80 & 4.47 & 1.30 & 6.50 & 7.17 & 6.50 & 1.35 \\
\hline 5 & 100 & 1.97 & 24.65 & 16.88 & 24.65 & 1.74 & 18.84 & 14.97 & 18.84 & 2.26 & 30.36 & 17.76 & 30.36 & 2.37 \\
\hline 10 & 100 & 2.57 & 39.70 & 20.49 & 39.70 & 2.37 & 31.20 & 18.42 & 31.20 & 2.73 & 44.30 & 22.84 & 44.30 & 2.86 \\
\hline 20 & 100 & 2.83 & 49.70 & 22.10 & 49.70 & 2.74 & 38.80 & 19.65 & 38.80 & 2.98 & 55.31 & 24.90 & 55.31 & 3.24 \\
\hline 1 & 200 & 1.04 & 10.80 & 10.29 & 5.40 & 0.81 & 6.66 & 8.17 & 3.33 & 1.15 & 12.05 & 10.44 & 6.02 & 1.20 \\
\hline 5 & 200 & 1.78, & 37.50 & 21.05 & 18.75 & 1.56 & 31.84 & 20.34 & 15.92 & 2.04 & 44.18 & 21.58 & 22.09 & 2.14 \\
\hline 10 & 200 & 2.35 & 61.20 & 25.96 & 30.60 & 2.16 & 53.70 & 24.76 & 26.85 & 2.50 & 65.50 & 26.13 & 32.75 & 2.63 \\
\hline 20 & 200 & 2.61 & 72.87 & 27.88 & 36.43 & 2.53 & 65.50 & 25.84 & 32.75 & 2.75 & 79.10 & 28.69 & 39.55 & 2.99 \\
\hline 1 & 250 & 0.94 & 8.82 & 9.37 & 3.52 & 0.72 & 6.63 & 9.10 & 2.65 & 1.03 & 10.50 & 10.14 & 4.20 & 1.08 \\
\hline 5 & 250 & 1.62 & 43.37 & 26.77 & 17.34 & 1.42 & 37.09 & 26.07 & 14.83 & 1.86 & 50.77 & 27.23 & 20.30 & 1.95 \\
\hline 10 & 250 & 2.17 & 72.20 & 33.2 & 28.88 & 1.99 & 62.10 & 31.07 & 24.84 & 2.31 & 79.26 & 34.23 & 31.70 & 2.43 \\
\hline 20 & 250 & 258 & 115.05 & 44.56 & 46.02 & 2.50 & 95.88 & 38.29 & 38.35 & 2.72 & 126.56 & 46.46 & 50.62 & 2.96 \\
\hline
\end{tabular}

\section{Conclusion}

The growth of Candida species was investigated in metal and metal-free media. Bioaccumulation experiments was carried out as a function of molasses sucrose and metal ion concentrations in a batch reactor. Initial pH and molasses sucrose directly affected the microbial growth. Candida yeasts showed maximum biomass concentration at $\mathrm{pH}$ 4.0. It was observed that the yeast concentrations and specific growth rates increased with increasing initial sucrose concentration. $\mathrm{Cu}(\mathrm{II})$ and $\mathrm{Ni}(\mathrm{II})$ ions inhibited specific growth rates and microorganism concentrations and the inhibition effect of $\mathrm{Ni}(\mathrm{II})$ ions on yeast growth was higher than $\mathrm{Cu}(\mathrm{II})$ ions for all yeasts. Maximum specific growth rate and microorganism concentration were determined as $0.253 \mathrm{~h}^{-1}$ and $2.854 \mathrm{~g} / \mathrm{L}$, $0.238 \mathrm{~h}^{-1}$ and $2.658 \mathrm{~g} \mathrm{/} \mathrm{L,} 0.289 \mathrm{~h}^{-1}$ and $2.999 \mathrm{~g} / \mathrm{L}$ and $0.308 \mathrm{~h}^{-1}$ respectively for Candida membranaefaciens, Candida utilis, Candida tropicalis ve Candida lypolitica in metal free media at $10 \mathrm{~g} / \mathrm{L}$ constant molasses sucrose concentration. Microoganism concentration was decreased from $3.111 \mathrm{~g} / \mathrm{L}$ to $2.968 \mathrm{~g} / \mathrm{L}$ with increasing initial $\mathrm{Cu}$ (II) concentration 0.0 to $100.0 \mathrm{mg} / \mathrm{L}$ for Candida lypolytica. Candida utilis showed the lowest specific growth rate and microorganism concentration among the yeasts $\left(0.207 \mathrm{~h}^{-1} ; 2.460 \mathrm{~g} / \mathrm{L}\right)$ whereas Candida lipolytica showed the highest specific growth rate and microorganism concentration. The relationship between the specific growth rate, molasses sucrose, and metal concentrations was determined by inhibition kinetics. It was observed that the maximum specific growth rates of microorganisms decreased with increasing initial $\mathrm{Cu}$ (II) and Ni (II) ion concentrations whereas saturation constants increased. It was observed that the bioaccumulated $\mathrm{Cu}$ (II) and Ni (II) ions and specific $\mathrm{Cu}$ (II) and Ni(II) uptake was increased with increasing initial sucrose and $\mathrm{Cu}(\mathrm{II})$ and $\mathrm{Ni}$ (II) concentrations. The amount of $\mathrm{Cu}$ (II) and Ni (II) ions uptake per gram dry microorganism increased with increasing the initial metal concentration up to $250 \mathrm{mg} / \mathrm{L}$. The microbial growth of Candida utilis was inhibited significantly due to increasing Cu(II) concentrations. Uptake efficiency of $\mathrm{Cu}$ (II) ions was higher than Ni (II), and Candida lypolitica performed the highest removal efficiency in medium containing both single Cu (II) and Ni (II) ions. The bioaccumulation capacity of Candida yeasts was increased due to the energy needs of the bioaccumulation process. The present study showed that Candida species appears to be useful biomass for removing heavy metal ions from wastewaters containing $\mathrm{Cu}(\mathrm{II})$ and $\mathrm{Ni}(\mathrm{II})$ ions. We hope that the study will help other researchers in choosing biomass due to metal resistance, economic, and efficient production of Candida yeasts for wastewater treatments.

\section{Abbreviations}




\begin{tabular}{|c|c|}
\hline$\mu_{\max }$ & : Maximum specific growth rate $\left(\mathrm{h}^{-1}\right)$ \\
\hline $\mathrm{C}_{\mathrm{iCu}}$ & : Initial Cu (II) ion concentration (mg / L) \\
\hline $\mathrm{C}_{\mathrm{iNi}}$ & : Initial Ni (II) ion concentration (mg / L) \\
\hline $\mathrm{C}_{\mathrm{acc}, \mathrm{Cu}}$ & : Bioaccumulated copper(II) ion concentration at any time (mg / L) \\
\hline $\mathrm{C}_{\mathrm{acc}, \mathrm{Ni}}$ & : Bioaccumulated copper(II) ion concentration at any time (mg/L) \\
\hline $\mathrm{K}_{\mathrm{s}}$ & : Saturation constant (g / L) \\
\hline $\mathrm{q}_{\mathrm{Cu}}$ & : Specific $\mathrm{Cu}(\mathrm{II})$ uptake defined as bioaccumulated $\mathrm{Cu}(\mathrm{II})$ ion quantity per gram of dried yeast at the end of microbial growth (mg/g) \\
\hline $\mathrm{q}_{\mathrm{Ni}}$ & : Specific $\mathrm{Ni}(\mathrm{II})$ uptake defined as bioaccumulated $\mathrm{Ni}(\mathrm{II})$ ion quantity per gram of dried yeast at the end of microbial growth (mg/g) \\
\hline $\mathrm{S}_{\mathrm{i}}$ & : Initial sucrose concentration (g / L) \\
\hline S & : Sucrose concentration (g / L) \\
\hline $\mathrm{t}$ & : Reaction time (h) \\
\hline $\mathrm{X}_{\max }$ & : Maximum dried yeast concentration (g / L) \\
\hline
\end{tabular}

\section{Declarations}

\section{Ethics approval and consent to participate}

Not applicable

\section{Consent for publication}

Not applicable

\section{Availability of data and materials}

Not applicable

\section{Competing interests}

The authors declare that they have no competing interests

\section{Funding}

The financial support provided by the Cumhuriyet University Scientific Research Projects Unit (BAP- M-354 coded project)

\section{Authors' contributions}

"ÜA analyzed the experimental data regarding the bioaccumulation and microbial growtht. GM performed the experimental study, and was a major contributor in writing the manuscript. All authors read and approved the final manuscript

\section{Acknowledgements}

The financial support provided by the Cumhuriyet University Scientific Research Projects Unit (BAP- M-354 coded project) is gratefully acknowledged.

\section{Author's information}

${ }^{1}$ Gülşah MERSiN (Cumhuriyet University, Faculty of Engineering, Chemical Engineering Department, 58140, Sivas, TURKEY)

${ }^{2}$ Ünsal AÇIKEL (Cumhuriyet University, Faculty of Engineering, Chemical Engineering Department, 58140, Sivas, TURKEY)

Corresponding Author: ${ }^{1}$ Gülşah MERSiN (Cumhuriyet University, Faculty of Engineering, Chemical Engineering Department, 58140, Sivas, TURKEY)

\section{References}

Abbas SH, Ismail IM, Mostafa TM, Sulaymon AH (2014) Biosorption of heavy metals: a review. J Chem Sci Technol 3:74-102. Available via http://paper.academicpub.org/Paper?id=15568. Accessed 26 September 2020

Açikel U, Alp T (2009) A study on the inhibition kinetics of bioaccumulation of $\mathrm{Cu}(\mathrm{II})$ and Ni(II) ions using Rhizopus delemar. J Hazard Mater 168(2-3):14491458. https://doi.org/10.1016/j.jhazmat.2009.03.040 
Aksu Z, Dönmez G (2003) A comparative study on the biosorption characteristics of some yeasts for Remazol Blue reactive dye. Chemosphere, 50(8):10751083. https://doi.org/10.1016/S0045-6535(02)00623-9

Aksu Z, Dönmez G (2000) The use of molasses in copper (II) containing wastewaters: effects on growth and copper (II) bioaccumulation properties of Kluyveromyces marxianus. Process Biochemistry 36(5):451-458. https://doi.org/10.1016/S0032-9592(00)00234-X

Anh Do T, Sakai T, Kishida M, Furuta M (2016) Isolation and characterization of a variant manganese resistant strain of Saccharomyces cerevisiae. Biocontrol Science 21:253-260. https://doi.org/10.4265/bio.21.253

Banafid W, Joutey NT, Asri M, Sayel H, Tirry N, Ghachtouli NE (2017) Yeast Biomass: An Alternative for Bioremediation of Heavy Metals. In Yeast- Industrial Applications. InTech. DOI: 10.5772/intechopen.70559

Bai D, Wang X, Huo D, Ying Q, Wang N, \& Xia B (2019) Coprecipitation Preparation of Cu/Zn/Al-Hydrotalcite-Like Compound for Copper Removal from Electroplating Wastewater. Journal of Chemistry 2019. https://doi.org/10.1155/2019/5347920

Bamforth CW, Cook DJ (2019) Food, fermentation and micro-organisms: Wiley-Blackwell.

Dönmez G, Aksu Z (2001) Bioaccumulation of copper(II) and nickel(II) by the non-adapted and adapted growing Candida sp. Water research 35(6):14251434. https://doi.org/10.1016/S0043-1354(00)00394-8

Dursun AY, Ulsu G, Cuci Y and Aksu Z (2003b) Bioaccumulation of copper(II), lead(II) and chromium(VI) by growing Aspergillus niger. ProcessBiochem 38:1647-1651. https://doi.org/10.1016/S0032-9592(02)00075-4

Fadel M, Hassanein NM, Elshafei MM, Mostafa AH, Ahmed MA \& Khater HM (2017) Biosorption of manganese from groundwater by biomass of Saccharomyces cerevisiae, HBRC Journal 13:(1) 106-113. https://doi.org/10.1016/j.hbrcj.2014.12.006

Fomina M, Gadd GM (2014) Biosorption: current perspectives on concept, definition and application. Bioresource technology 160: 3-14.

https://doi.org/10.1016/j.biortech.2013.12.102

Forouchi E, Gunn DJ (1983) Some effects of metal ions on the estimation of reducing sugars in biological media. Biotechnol. Bioeng 25: $1905-1911$. https://doi.org/10.1002/bit.260250717

Gönen F, Aksu Z (2008) Use of response surface methodology (RSM) in the evaluation of growth and copper(II) bioaccumulation properties of Candida utilis in molasses medium. Journal of hazardous materials 154(1-3): 731-738. https://doi.org/10.1016/j.jhazmat.2007.10.086

Honfi K, Tálos K, Kőnig-Péter A, Kilár F, Pernyeszi T (2016) Copper(II) and Phenol Adsorption by Cell Surface Treated Candida tropicalis Cells in Aqueous Suspension. Water, Air, \& Soil Pollution, 227: 1-14. https://doi.org/10.1007/s11270-016-2751-0

Horsfall JM, Spiff Al (2005) Effects of temperature on the sorption of Pb2+ and Cd2+ from aqueous solution by Caladium bicolor (Wild Cocoyam) biomass. Electronic Journal of Biotechnology 8(2):43-50. DOI: 10.2225/vol8-issue2-fulltext-4

Joseph SP (2009) Process Optimization for Mass Production of Marine Yeast Candida sp. S 27 and its Nutritional Characterization. PhD thesis, Cochin University of Science and technology.

Kujan P, Votruba J, Kameník V (1995) Substrate dependent bioaccumulation of cadmium by growing yeast Candida utilis. Folia Microbiol 40:288-292. https://doi.org/10.1007/BF02814210

Luk CHJ, Yip J, Yuen CWM. et al. (2017) Biosorption Performance of Encapsulated Candida krusei for the removal of Copper(II). Sci Rep 7:2159.

https://doi.org/10.1038/s41598-017-02350-7

Monod J (1949) The growth of bacterial cultures. Available via Annu. Rev. Microbiol. 1949.3:371-394. Downloaded from www.annualreviews.org by Marine Biological Laboratory - Woods Hole Oceanographic Institution on 06/15/14. For personal use only.

Muñoz A, Ruiz E, Abriouel H, Gálvez A, Ezzouhri L, Lairini K, Espínola F (2012) Heavy metal tolerance of microorganisms isolated from wastewaters: Identification and evaluation of its potential for biosorption. Chemical Engineering Journal 210:325-32. https://doi.org/10.1016/j.cej.2012.09.007

Muter O, Lubinya I, Millers D, Grigorjeva L, Ventinya E, Rapoport A (2002) Cr (VI) sorption by intact and dehydrated Candida utilis cells in the presence of other metals. Process Biochemistry 38(1):123-31. https://doi.org/10.1016/S0032-9592(02)00065-1

Oztürk A (2007) Removal of nickel from aqueous solution by the bacterium Bacillus thuringiensis. J Hazard Mater 147(1-2):518-523.

https://doi.org/10.1016/j.jhazmat.2007.01.047

Pabst MW, Miller CD, Dimkpa CO, Anderson AJ, McLean JE (2010) Defining the surface adsorption and internalization of copper and cadmium in a soil bacterium, Pseudomonas putida. Chemosphere 81(7):904-910. https://doi.org/10.1016/j.chemosphere.2010.07.069

Ramírez-Ramírez R, Calvo-Méndez C, Ávila-Rodríguez M. et al. (2004) Cr(VI) reduction in a chromate-resistant strain of Candida maltosa isolated from the leather industry. Antonie Van Leeuwenhoek 85:63-68. https://doi.org/10.1023/B:ANTO.0000020151.22858.7f

Page $9 / 11$ 
Ricica J (1971) Continuous cultivation of microorganisms. Folia microbiologica 16(5):389-415. https://doi.org/10.1007/BF02884111

Sağ Y (2001) Biosorption Of Heavy Metals By Fungal Bıomass And Modeling Of Fungal Biosorption: A Review, Separation and Purification Methods 30(1):148. https://doi.org/10.1081/SPM-100102984

Snell FD, Snell CT (1959) Colorimetric Methods of Ananysis: Including Photometric Methods. Published by D. Van Nostrand Company.

Tchounwou P B, Yedjou CG, Patlolla AK, Sutton DJ (2012) Heavy metal toxicity and the environment. Experientia supplementum 101: $133-164$.

https://doi.org/10.1007/978-3-7643-8340-4_6

Vadkertiová R, Sláviková E (2006) Metal tolerance of yeasts isolated from water, soil and plant environments. J. Basic Microbiol 46: 145-152.

https://doi.org/10.1002/jobm.200510609

Wang J, Chen C (2006) Biosorption of heavy metals by Saccharomyces cerevisiae: a review. Biotechnol Adv 24(5):427-451.

https://doi.org/10.1016/j.biotechadv.2006.03.001

Wilde EW \& Benemann JR (1993) Bioremoval of heavy metals by the use of microalgae. Biotechnology advances 11(4), 781-812.

https://doi.org/10.1016/0734-9750(93)90003-6

Yin $\mathrm{H}, \mathrm{He} \mathrm{B}$, Peng H, et al. (2008) Removal of $\mathrm{Cr}(\mathrm{VI})$ and $\mathrm{Ni}(\mathrm{II})$ from aqueous solution by fused yeast: study of cations release and biosorption mechanism. Journal of Hazardous Materials 158(2-3):568-576. https://doi.org/10.1016/j.jhazmat.2008.01.113

\section{Figures}

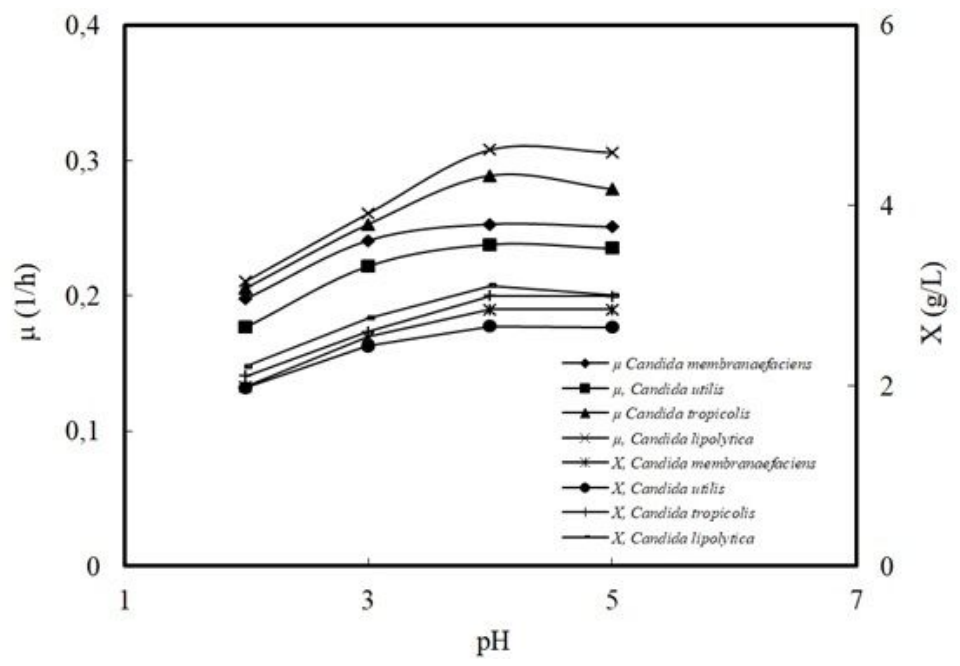

Figure 1

Effect of initial pH on specific growth rate and microorganism concentration for Candida lypolytica, Candida utilis, Candida tropicalis and Candida membranefeciens yeasts (So: $10 \mathrm{~g} / \mathrm{L} ; \mathrm{T}: 250 \mathrm{C}$; SR: $150 \mathrm{rpm}$ )

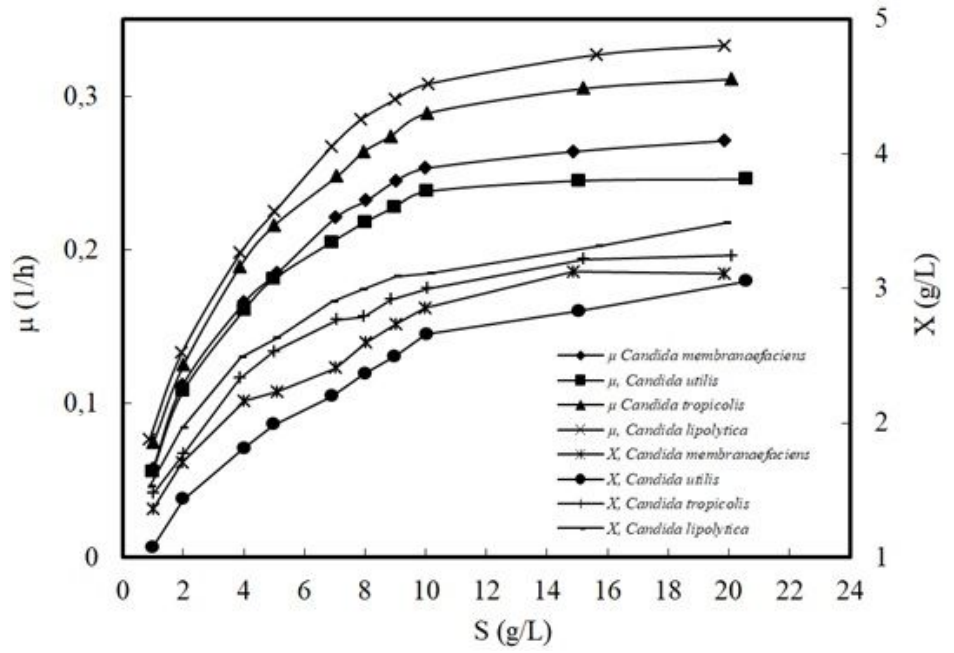

Figure 2

Page 10/11 
Effect of initial sucrose concentration on specific growth rate and microorganism concentration for Candida lypolytica, Candida utilis, Candida tropicalis and Candida membranaefaciens yeasts (pH: 4, T: 25oC; SR: $150 \mathrm{rpm}$ )

\section{Supplementary Files}

This is a list of supplementary files associated with this preprint. Click to download.

- graphicalabstract.tif 